\title{
Influence of different sowing density in two varieties of maize. Part I. Relation to yielding
}

\author{
Katarzyna Ambroży-Deręgowska ${ }^{1}$, Piotr Szulc ${ }^{2}$ \\ ${ }^{1}$ Department of Mathematical and Statistical Methods, Poznań University of Life Sciences, \\ Wojska Polskiego 28, 60-637 Poznań, Poland, e-mail: katarzyna.ambrozy@up.poznan.pl \\ ${ }^{2}$ Department of Agronomy, Poznań University of Life Sciences, Dojazd 11, 60-632 Poznań, \\ Poland, e-mail: piotr.szulc@up.poznan.pl
}

\section{SUMMARY}

\begin{abstract}
A study was carried out to determine the effect of sowing density on the yield of maize of two different varieties. The field experiment was carried out in 2012-2014 at the Department of Agronomy of Poznań University of Life Sciences. The first-order factor was the variety: SY Cooky and Drim "stay-green"; the second-order factor was sowing density: $6,7,8,9,10$ plants per $\mathrm{m}^{2}$. Weather conditions during the maize growing seasons significantly influenced the values of the studied traits. Significantly the lowest green mass yield of maize was obtained at the sowing density of 6 plants $\mathrm{m}^{-2}$, and the highest for 10 plants $\mathrm{m}^{-2}$. The "stay-green" variety significantly responded to an increase in sowing density with reduced fresh weight of leaf blades of a single plant compared with the conventional variety. This indicated highly effective photosynthesis with a lower plant density per unit area, which is also the basis for effective absorption of solar radiation for these maize varieties.
\end{abstract}

Key words: fresh weight yield, maize, sowing density, split-split-plot design, Tukey’s test

\section{Introduction}

Utilization of the yield-forming potential of new maize varieties is possible provided that agricultural practices are adapted to their requirements (Zielewicz et al. 2021). One of the most important factors is the sowing density, which largely determines the grain yield (Szmigiel and Oleksy 2004, Greveniotis et al. 2019). The sowing density determines the supply of water and nutrients to plants, as well as the access of light to individual plants, which is essential for efficient photosynthesis (Farnham 2001, Vafias et al. 2007). Optimal planting density is 
based on sowing of the number of plants recommended by breeders, but also their even distribution in rows. Only such an arrangement guarantees a maximum number of well-grained cobs, resulting in higher yields or improved energy value of the silage (Szulc et al. 2021). It should also be noted that incorrect plant density can no longer be corrected by any other agricultural measure (Li and Wang 2009). The range of optimal density is also highly dependent on weather conditions. Maize is a very water-efficient species, using only about 250 liters of water to produce $1 \mathrm{~kg}$ dry weight. Other cultivated species are much less effective in this regard. Spring wheat, for example, needs as much as approx. 432 liters of water to produce $1 \mathrm{~kg}$ dry weight (Sulewska 2007). However, the very high productivity of maize means that the crop utilizes large amounts of water per unit area - up to 16 million 1/ha. In view of the recurring periods of drought experienced almost every year, it becomes important to reduce the number of maize plants per unit area (Yu et al. 2019). As a result, plants on plantations would have better conditions for growth and yielding. Determination of the variable response of maize to different sowing densities can help increase its yields, maize being a species that is particularly sensitive to deviations from optimum canopy density (Xu et al. 2021). Earlier work by one of the present authors (Szulc et al. 2020) showed that the "stay-green" hybrid had significantly higher grain yield than the conventional variety. At the same time, this maize variety was characterized by higher values for 1000 seed weight, number of production cobs per unit area and grain water content at harvest. The aim of this field study was to determine the response of two types of maize varieties to different plant density, expressed by the yield of green maize mass intended for ensiling.

\section{Materials and methods}

\subsection{Experimental field}

The field experiment was carried out at the Department of Agronomy of Poznan University of Life Sciences, on the fields of the Agricultural Experimental Station in Swadzim (52 $\left.26^{\prime} \mathrm{N} ; 1^{\circ} 45^{\prime} \mathrm{E}\right)$ in the years $2012-2014$. It was carried out over 
3 years in the same split-plot design with 4 blocks. The following factors were studied: A - first-order factor: type of maize hybrid, A1 - SY Cooky, A2 - Drim, "stay-green" type; B - second-order factor: sowing density, B1 - 6 pcs m$^{-2}$, B2 7 pcs $\mathrm{m}^{-2}, \mathrm{~B} 3-8 \mathrm{pcs} \mathrm{m}^{-2}, \mathrm{~B} 4-9 \mathrm{pcs} \mathrm{m}^{-2}$, B5 $-10 \mathrm{pcs} \mathrm{m}^{-2}$. The same level of nitrogen, phosphorus and potassium fertilization was applied for all experimental objects, in the following doses: $120 \mathrm{~kg} \mathrm{~N} \cdot \mathrm{ha}^{-1}, 70 \mathrm{~kg} \mathrm{P}_{2} \mathrm{O}_{5} \cdot \mathrm{ha}^{-1}$ and $130 \mathrm{~kg} \mathrm{~K}_{2} \mathrm{O} \cdot \mathrm{ha}$ ${ }^{1}$. Fertilizers were applied in early spring under a cultivator. Nitrogen was applied in the form of ammonia, phosphorus in triple granulated superphosphate, and potassium in the form of potassium salt.

\subsection{Weather conditions}

The characteristics of the climatic conditions that prevailed during the research period are based on data from the meteorological station belonging to the Department of Agronomy of Poznań University of Life Sciences, located on the premises of the Agricultural Experimental Station in Swadzim (52 $26^{\prime} \mathrm{N} ; 16^{\circ} 45$ E). Thermal conditions during maize cultivation in the experimental years were similar to each other and amounted on average to $15.4{ }^{\circ} \mathrm{C}$ in $2012,15.6{ }^{\circ} \mathrm{C}$ in 2013 , and $16.1^{\circ} \mathrm{C}$ in the warmest year of 2014 . There were significantly greater differences between years in the amount of precipitation. The highest sum of rainfall was recorded in 2012 (473.6 $\mathrm{mm})$, which was $76.2 \mathrm{~mm}$ higher than in 2013 and $121.8 \mathrm{~mm}$ higher than in 2014 (Table 1).

\subsection{Observations and measurements}

Weight measurements of whole plants were carried out during the harvesting of maize for silage. On this basis, the yield of green mass of whole plants was determined (stem + leaves + ear). For this purpose, plants from $2 \mathrm{~m}^{2}$ were cut out from each experimental plot, and this yield was subsequently converted into the green mass yield $\left(\mathrm{tha}^{-1}\right)$. The silage maize was harvested during the period of appearance of black spots at the base of the kernel. This is the optimal time for 
Table 1. Average monthly air temperature and monthly sum of atmospheric precipitation in Swadzim for the growing season

\begin{tabular}{ccccccccc}
\hline \multirow{2}{*}{ Years } & \multicolumn{7}{c}{ Temperature [ $\left.{ }^{\circ} \mathrm{C}\right]$} \\
& IV & V & VI & VII & VIII & IX & X & Mean/Sum \\
\hline 2012 & 9.3 & 16.3 & 17.0 & 20.0 & 19.8 & 15.0 & 8.6 & 15.4 \\
2013 & 8.9 & 15.6 & 18.4 & 22.0 & 20.2 & 13.2 & 10.8 & 15.6 \\
2014 & 11.4 & 14.6 & 17.9 & 23.2 & 18.8 & 16.0 & 11.2 & 16.1 \\
$1957-2013$ & 11.4 & 14.6 & 17.9 & 23.2 & 18.8 & 16.0 & 11.2 & 16.1 \\
\hline Years & & \multicolumn{7}{c}{ Precipitation [mm] } \\
\hline 2012 & 17.4 & 84.4 & 118.1 & 136.2 & 52.7 & 28.4 & 36.4 & 473.6 \\
2013 & 10.5 & 95.5 & 114.9 & 52.9 & 32.4 & 75.9 & 15.3 & 397.4 \\
2014 & 50.3 & 80.7 & 44.6 & 51.5 & 56.5 & 39.2 & 29.0 & 351.8 \\
$1957-2013$ & 31.4 & 54.1 & 59.0 & 76.0 & 57.8 & 43.8 & 37.3 & 359.4 \\
\hline
\end{tabular}

harvesting this crop for silage. When considering maize varieties with the same FAO number, the dry matter content in the silage material is $38 \%$ (regardless of the tested experimental factors).

\subsection{Statistical analysis}

Statistical analyses, including analysis of variance (ANOVA) and the Tukey HSD (honestly significant difference) test for pairwise comparisons of means, were performed separately for the years of the study and for 2012-2014, according to the experimental data models designed as a split-plot experiment type (Szulc et al. 2016). All calculations were performed using Statistica 13 (2017) and MS Excel. Statistical significance was taken as p-value $<0.05$.

\section{Results}

The different weather conditions in the years covered by the study (2012-2014) are reflected in four of the considered traits, i.e. the weight of ears (g), the weight of stems $(\mathrm{g})$, the fresh mass of one plant $(\mathrm{g})$, and the yield of fresh mass $\left(\mathrm{tha}^{-1}\right)$; see Table 2 and Table 3. 
The results in Table 3 indicate that, irrespective of the experimental factors (A and B), significantly the lowest mean weight of ears (112.20 g), mean weight of stems (148.75 g), mean fresh mass of one plant (418.90 g) and mean yield of fresh mass (33.22 tha ${ }^{-1}$ ) were obtained in 2012. For the remaining years (20132014) these values (except the mean weight of stems) were significantly higher and did not differ significantly between those two years. The highest mean weight of stems was obtained in 2013 (437.35 g).

Moreover, the tested types of maize hybrid (A) significantly influenced the above-mentioned traits. The highest mean of weight of leaf $(162.13 \mathrm{~g})$, weight of ears (177.94 g), weight of stems (312.62 g), fresh mass of one plant (652.69 g) and yield of fresh mass (51.23 tha ${ }^{-1}$ ) were obtained for cultivar A2 (Drim "staygreen") (Table 3).

Over the study years, the results also indicate the significant impact of sowing density (B) on the considered traits of maize (Table 2 and Table 3). The highest mean weight of leaf (171.10 g) and the highest mean weight of stems (336.08 g) were found at seeding density B1 $\left(6 \mathrm{pcs} . \mathrm{m}^{-2}\right)$; they did not differ significantly from the means for densities B2 $\left(7\right.$ pcs. $\left.\mathrm{m}^{-2}\right)$ and B3 $\left(8\right.$ pcs. $\left.\mathrm{m}^{-2}\right)$, but differed significantly from the means for densities B4 $\left(9\right.$ pcs. $\left.\mathrm{m}^{-2}\right)$ and B5 (10 pcs. $\left.\mathrm{m}^{-2}\right)$. Similarly, sowing density B1 $\left(6 \mathrm{pcs} . \mathrm{m}^{-2}\right)$ produced the highest means of weight of ears $(210.91 \mathrm{~g})$ and fresh mass of one plant $(718.09 \mathrm{~g})$. These did not differ significantly from the means for density B2 $\left(7 \mathrm{pcs} . \mathrm{m}^{-2}\right)$. The lowest mean weight of ears (137.23 g) was found at seeding density B5 $\left(10 \mathrm{pcs} . \mathrm{m}^{-2}\right)$; it did not differ significantly from the means for densities B4 $\left(9\right.$ pcs. $\left.\mathrm{m}^{-2}\right)$ and B3 $\left(8 \mathrm{pcs} . \mathrm{m}^{-2}\right)$. The lowest mean fresh mass of one plant (558.69 g) was also observed at seeding density B5 $\left(10\right.$ pcs. $\left.\mathrm{m}^{-2}\right)$; it did not differ significantly from the mean for density B4 $\left(9\right.$ pcs. $\left.\mathrm{m}^{-2}\right)$. However, the highest mean yield of fresh mass $\left(55.55 \mathrm{tha}^{-1}\right)$ was observed at seeding density B5 $\left(10 \mathrm{pcs} . \mathrm{m}^{-2}\right)$; it did not differ significantly from the means for densities B4 $\left(9\right.$ pcs. $\left.\mathrm{m}^{-2}\right)$ and B3 $\left(8\right.$ pcs.m $\left.{ }^{-2}\right)$, but differed significantly from the means for densities B2 $\left(7\right.$ pcs. $\left.\mathrm{m}^{-2}\right)$ and B1 $\left(6\right.$ pcs. $\left.\mathrm{m}^{-2}\right)$. 
Table 2. Results of three-stratum (YAB) ANOVA

\begin{tabular}{|c|c|c|c|c|c|c|}
\hline \multirow{2}{*}{$\begin{array}{c}\text { Source } \\
\text { of } \\
\text { variability }\end{array}$} & \multirow{2}{*}{$\begin{array}{l}\text { Degrees } \\
\text { of } \\
\text { freedom }\end{array}$} & \multicolumn{5}{|c|}{ Mean squares } \\
\hline & & $\begin{array}{l}\text { Weight of } \\
\text { leaf } \\
(\mathrm{g})\end{array}$ & $\begin{array}{l}\text { Weight of } \\
\text { ears } \\
(\mathrm{g})\end{array}$ & $\begin{array}{l}\text { Weight of } \\
\text { stems } \\
(\mathrm{g})\end{array}$ & $\begin{array}{l}\text { Fresh mass of one } \\
\text { plant }(\mathrm{g})\end{array}$ & $\begin{array}{c}\text { Yield of fresh } \\
\text { mass } \\
\left(\mathrm{t} \cdot \mathrm{ha}^{-1}\right)\end{array}$ \\
\hline Blocks & 3 & 2524.53 & 2256.95 & 7577.29 & 32116.14 & 230.78 \\
\hline $\mathrm{Y}$ & 2 & 139.03 & $94310.64 * *$ & $847730.36^{* *}$ & $1437814.69 * *$ & $8466.85 * *$ \\
\hline Error 1 & 6 & 1774.42 & 652.44 & 6387.34 & 14271.84 & 82.15 \\
\hline A & 1 & $2658.80 *$ & $12075.62 *$ & $8555.63^{*}$ & $64490.24 * *$ & $381.59 * *$ \\
\hline $\mathrm{Y} \times \mathrm{A}$ & 2 & $2732.41 * *$ & 4704.73 & 4011.83 & $21032.46^{*}$ & $166.24 * *$ \\
\hline Error 2 & 9 & 258.08 & 2081.66 & 1178.72 & 3434.25 & 18.39 \\
\hline B & 4 & $1845.27 * *$ & $22151.86^{* *}$ & $18024.69 * *$ & $104257.19 * *$ & $525.95 * *$ \\
\hline $\mathrm{Y} \times \mathrm{B}$ & 8 & 208.65 & 980.95 & $9043.31 * *$ & $15479.46^{* *}$ & 16.89 \\
\hline $\mathrm{A} \times \mathrm{B}$ & 4 & $820.56^{*}$ & 422.48 & 1846.35 & 5152.04 & 12.98 \\
\hline $\mathrm{Y} \times \mathrm{A} \times \mathrm{B}$ & 8 & 85.90 & 499.86 & 2390.32 & 1838.29 & 16.88 \\
\hline Error 3 & 72 & 296.39 & 1722.80 & 2966.29 & 4477.03 & 30.76 \\
\hline
\end{tabular}

Table 3. Mean values of the traits for years and agrotechnical factors

\begin{tabular}{|c|c|c|c|c|c|c|}
\hline Factors & $\begin{array}{l}\text { Levels } \\
\text { of } \\
\text { factors }\end{array}$ & $\begin{array}{c}\text { Weight of } \\
\text { leaf } \\
(\mathrm{g})\end{array}$ & $\begin{array}{c}\text { Weight of } \\
\text { ears } \\
(\mathrm{g})\end{array}$ & $\begin{array}{l}\text { Weight of } \\
\text { stems } \\
(\mathrm{g})\end{array}$ & $\begin{array}{l}\text { Fresh mass of } \\
\text { one plant } \\
(\mathrm{g})\end{array}$ & $\begin{array}{l}\text { Yield of fresh } \\
\text { mass }\left(\mathrm{tha}^{-1}\right)\end{array}$ \\
\hline \multirow{3}{*}{ Y } & 2012 & $157.95 n s$ & $112.20 \mathrm{~b}$ & $148.75 \mathrm{c}$ & $418.90 \mathrm{~b}$ & $33.22 \mathrm{~b}$ \\
\hline & 2013 & $158.97 n s$ & $190.27 \mathrm{a}$ & $437.35 \mathrm{a}$ & $786.59 a$ & $61.32 \mathrm{a}$ \\
\hline & 2014 & $155.35 n s$ & $201.26 \mathrm{a}$ & $326.41 \mathrm{~b}$ & $683.02 \mathrm{a}$ & $53.80 \mathrm{a}$ \\
\hline \multirow{2}{*}{ A } & A1 & $152.72 \mathrm{~b}$ & $157.88 \mathrm{~b}$ & $295.73 \mathrm{~b}$ & $606.32 \mathrm{~b}$ & $47.66 \mathrm{~b}$ \\
\hline & A2 & $162.13 \mathrm{a}$ & $177.94 \mathrm{a}$ & $312.62 \mathrm{a}$ & $652.69 \mathrm{a}$ & $51.23 \mathrm{a}$ \\
\hline \multirow{5}{*}{ B } & B1 & $171.10 \mathrm{a}$ & $210.91 \mathrm{a}$ & $336.08 \mathrm{a}$ & $718.09 \mathrm{a}$ & $43.32 \mathrm{c}$ \\
\hline & B2 & $158.59 \mathrm{ab}$ & $183.21 \mathrm{ab}$ & $325.78 \mathrm{ab}$ & $667.58 \mathrm{ab}$ & $46.60 \mathrm{bc}$ \\
\hline & B3 & $157.91 \mathrm{ab}$ & $166.07 \mathrm{bc}$ & $305.03 \mathrm{abc}$ & $629.02 \mathrm{bc}$ & $50.25 \mathrm{ab}$ \\
\hline & B4 & $150.60 \mathrm{~b}$ & $142.13 \mathrm{c}$ & $281.42 \mathrm{bc}$ & $574.14 \mathrm{~cd}$ & $51.50 \mathrm{ab}$ \\
\hline & B5 & $148.92 \mathrm{~b}$ & $137.23 \mathrm{c}$ & $272.54 \mathrm{c}$ & $558.69 \mathrm{~d}$ & $55.55 \mathrm{a}$ \\
\hline
\end{tabular}

Values in columns marked with at least one letter the same do not differ significantly $(\alpha=0.05)$. $n s-$ not significant 
It was observed (Table 2 and Table 4) that the tested types of maize hybrid (A) reacted differently to the changing conditions over the study years in terms of the weight of leaf, the fresh mass of one plant and the yield of fresh mass.

As concerns the weight of leaf, the only significant difference occurred in 2012, when cultivar A2 obtained a significantly higher mean weight of leaf (170.66 g) than cultivar A1 (145.24 g) (Table 4).

The highest means of fresh mass of one plant $(829.02 \mathrm{~g})$ and yield of fresh mass (64.84 tha $\left.{ }^{-1}\right)$ were recorded for cultivar A2 (Drim "stay-green") in 2013. The lowest means of fresh mass of one plant and yield of fresh mass were observed for variety A1 (SY Cooky) and A2 (Drim "stay-green") in 2012.

It was found (Table 2 and Table 4) that the tested sowing densities (B) produced different reactions to the changing conditions over the study years, but only for weight of stems and fresh mass of one plant. For the remaining traits, no significant interactions between year $(\mathrm{Y})$ and sowing density (B) were found.

The highest mean weight of stems (515.44 g) was obtained in 2013 with sowing density B1 $\left(6 \mathrm{pcs} . \mathrm{m}^{-2}\right)$. This mean did not differ significantly from the means obtained in the same year for sowing densities B2 $\left(7\right.$ pcs. $\left.{ }^{-2}\right)$ and B3 (8 pcs. $\mathrm{m}^{-2}$ ). The lowest means were obtained for all sowing densities in 2012 .

The lowest means for fresh mass of one plant were also obtained for all sowing densities in 2012. The highest mean fresh mass of one plant (937.15 g) was obtained in 2013 with sowing density B1 $\left(6 \mathrm{pcs} . \mathrm{m}^{-2}\right)$. This mean did not differ significantly from the mean obtained in the same year for sowing density B2 (7 pcs. $\left.\mathrm{m}^{-2}\right)$.

A significant interaction was found between cultivar (A) and sowing density (B), although only for the weight of leaf (Table 2 and Figure 1).

The highest mean weight of leaf (180.38 g) was obtained for cultivar A2 (Drim "stay-green") with sowing density B1. This mean did not differ significantly from the means obtained for the same cultivar with sowing densities B2 (170.14 g) and B3 (162.93 g), or from the mean obtained for cultivar A1 (SY Cooky) with sowing density B1 (161.82 g). The lowest mean leaf weight was observed for cultivar A1 with sowing density B2 (147.05 g). This did not differ 
Table 4. Mean values for the combinations $\mathrm{Y} \times \mathrm{A}$ and $\mathrm{Y} \times \mathrm{B}$

\begin{tabular}{|c|c|c|c|c|c|c|}
\hline $\mathrm{Y}$ & A & $\begin{array}{l}\text { Weight of } \\
\text { leaf }(\mathrm{g})\end{array}$ & $\begin{array}{l}\text { Weight of } \\
\text { ears }(g)\end{array}$ & $\begin{array}{l}\text { Weight of } \\
\text { stems } \\
(\mathrm{g})\end{array}$ & $\begin{array}{l}\text { Fresh mass of } \\
\text { one plant }(\mathrm{g})\end{array}$ & $\begin{array}{c}\text { Yield of } \\
\text { fresh mass } \\
\left(\mathrm{t}^{-} \mathrm{ha}^{-1}\right)\end{array}$ \\
\hline \multirow{2}{*}{2012} & A1 & $145.24 \mathrm{~b}$ & 109.33 & 135.03 & $389.60 \mathrm{c}$ & $30.92 \mathrm{c}$ \\
\hline & $\mathrm{A} 2$ & $170.66 \mathrm{a}$ & 115.07 & 162.48 & $448.21 \mathrm{c}$ & $35.51 \mathrm{c}$ \\
\hline \multirow{2}{*}{2013} & $\mathrm{~A} 1$ & $153.75 \mathrm{ab}$ & 167.76 & 422.64 & $744.15 \mathrm{~b}$ & $57.80 \mathrm{~b}$ \\
\hline & $\mathrm{A} 2$ & $164.18 \mathrm{ab}$ & 212.78 & 452.06 & $829.02 \mathrm{a}$ & $64.84 \mathrm{a}$ \\
\hline \multirow{2}{*}{2014} & A1 & $159.15 \mathrm{ab}$ & 196.54 & 329.52 & $685.21 \mathrm{~b}$ & $54.26 \mathrm{~b}$ \\
\hline & $\mathrm{A} 2$ & $151.55 \mathrm{ab}$ & 205.98 & 323.31 & $680.83 \mathrm{~b}$ & $53.34 \mathrm{~b}$ \\
\hline \multirow[t]{3}{*}{$\mathrm{Y}$} & B & $\begin{array}{l}\text { Weight of } \\
\text { leaf }(\mathrm{g})\end{array}$ & $\begin{array}{l}\text { Weight of } \\
\text { ears }(g)\end{array}$ & $\begin{array}{l}\text { Weight of } \\
\text { stems } \\
(\mathrm{g})\end{array}$ & $\begin{array}{l}\text { Fresh mass of } \\
\text { one plant }(\mathrm{g})\end{array}$ & $\begin{array}{c}\text { Yield of } \\
\text { fresh mass } \\
\left(\mathrm{t}^{-} \mathrm{ha}^{-1}\right)\end{array}$ \\
\hline & B1 & 165.25 & 145.08 & $128.53 \mathrm{e}$ & $438.86 \mathrm{e}$ & 26.51 \\
\hline & B2 & 155.09 & 119.53 & $165.99 \mathrm{e}$ & $440.61 \mathrm{e}$ & 30.93 \\
\hline \multirow[t]{5}{*}{2012} & B3 & 166.71 & 118.86 & $139.17 \mathrm{e}$ & $424.74 \mathrm{e}$ & 33.98 \\
\hline & B4 & 151.97 & 95.51 & $165.69 \mathrm{e}$ & $413.17 \mathrm{e}$ & 37.10 \\
\hline & B5 & 150.74 & 82.02 & $144.38 \mathrm{e}$ & $377.14 \mathrm{e}$ & 37.56 \\
\hline & B1 & 174.81 & 246.89 & $515.44 \mathrm{a}$ & $937.15 \mathrm{a}$ & 56.45 \\
\hline & B2 & 161.49 & 208.40 & $462.43 \mathrm{ab}$ & $832.32 \mathrm{ab}$ & 57.64 \\
\hline \multirow[t]{5}{*}{2013} & B3 & 157.86 & 191.88 & $441.40 \mathrm{abc}$ & $791.13 \mathrm{bc}$ & 63.07 \\
\hline & B4 & 151.64 & 151.48 & $390.10 \mathrm{bcd}$ & $693.22 \mathrm{~cd}$ & 62.09 \\
\hline & B5 & 149.03 & 152.70 & $377.39 \mathrm{bcd}$ & $679.12 \mathrm{~cd}$ & 67.35 \\
\hline & $\mathrm{B} 1$ & 173.23 & 240.74 & $364.28 \mathrm{bcd}$ & $778.25 \mathrm{bc}$ & 47.01 \\
\hline & B2 & 159.19 & 221.69 & $348.92 \mathrm{~cd}$ & $729.80 \mathrm{bcd}$ & 51.23 \\
\hline \multirow[t]{3}{*}{2014} & B3 & 149.16 & 187.48 & $334.53 \mathrm{~cd}$ & $671.18 \mathrm{~cd}$ & 53.69 \\
\hline & B4 & 148.18 & 179.39 & $288.47 \mathrm{~d}$ & $616.04 \mathrm{~d}$ & 55.32 \\
\hline & B5 & 146.98 & 176.98 & $295.86 \mathrm{~d}$ & $619.82 d$ & 61.73 \\
\hline
\end{tabular}

Values in columns marked with at least one letter the same do not differ significantly $(\alpha=0.05)$.

significantly from the means obtained for the same cultivar with other sowing densities - B1 (161.82 g), B3 (152.89 g), B4 (151.39 g), B5 (150.44 g) - or from the means obtained for cultivar A2 with sowing densities B3 (162.93 g), B4 $(149.81 \mathrm{~g})$ and B5 (147.39 g).

In the analysis of variance there was no significant interaction of both factors with the years of research. 


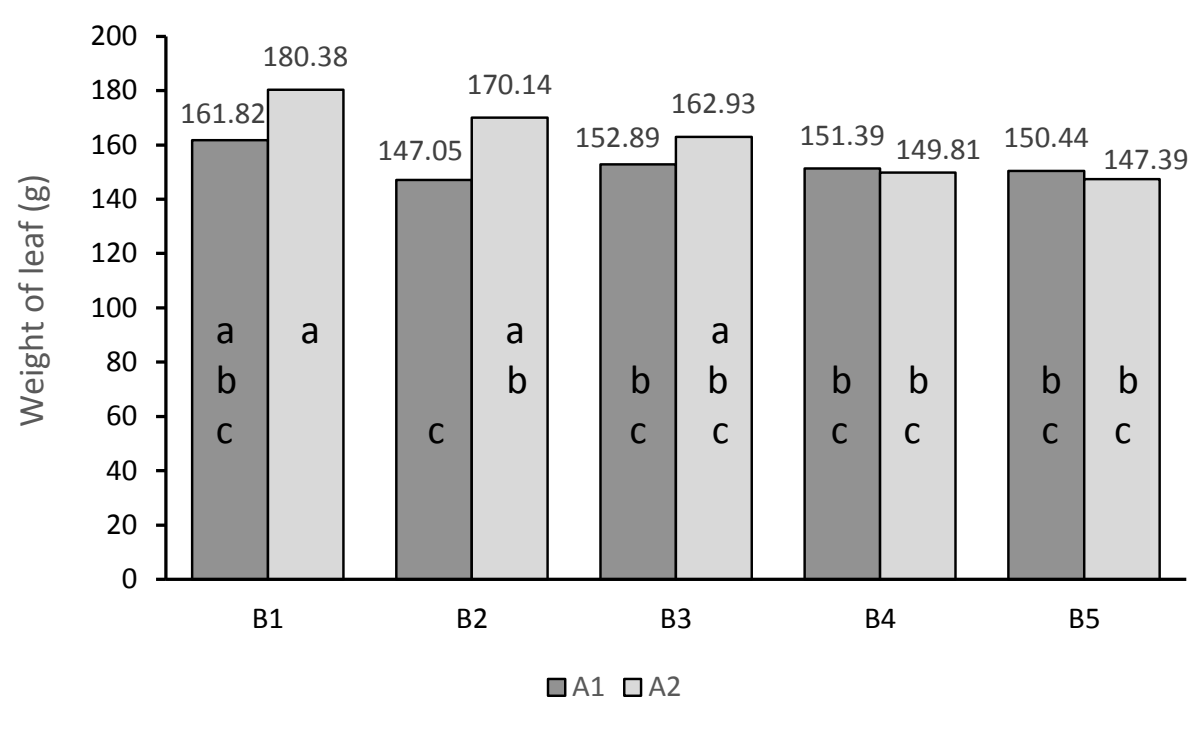

a, b, c- homogeneous groups $(\alpha=0.05)$

Figure 1. Mean values of weight of leaf ( $\mathrm{g}$ ) for the combinations of two varieties and five sowing densities $(\mathrm{A} \times \mathrm{B})$.

\section{Conclusions}

1. Weather conditions during maize growing seasons significantly influenced the values of the studied traits.

2. The "stay-green" maize variety was characterized by significantly higher mean fresh weight of a single plant (leaves, stem, cob), which had consequences for the mean yield of fresh weight per unit area.

3. An increase in maize sowing density from 6 to 10 plants $\mathrm{m}^{-2}$ reduced the mean fresh weight of leaf blades, stems and cob of a single maize plant.

4. Significantly the lowest mean green maize mass yield was obtained at the sowing density of 6 plants $\mathrm{m}^{-2}$, and the highest for 10 plants $\mathrm{m}^{-2}$.

5. The "stay-green" variety significantly responded to an increase in sowing density with a decrease in the fresh weight of leaf blades per plant, compared with the conventional variety. This indicates highly effective photosynthesis with a 
lower plant density per unit area, which is also the basis for the effective absorption of solar radiation for these maize varieties.

\section{REFERENCES}

Farnham D.E. (2001): Row spacing, plant density and hybrid effects on corn grain yield and moisture. Agronomy Journal 93: 1049-1053.

Greveniotis V., Zotis S., Sioki E., Ipsilandis C. (2019): Field population density effects on field yield and morphological characteristics of maize. Agriculture 9: 160.

Li S.K., Wang C.T. (2009): Review of maize production technology in China. Sci. Agric. Sin. 42: 1941-1951.

Sulewska H. (2007): Wymagania środowiskowe kukurydzy. Integrowana produkcja kukurydzy. Opracowanie zbiorowe pod redakcją Kaniuczaka i Pruszyńskiego. ss. 69. IOR Poznan.

Szmigiel A., Oleksy A. (2004): Wpływ gęstości siewu na plon odmian kukurydzy o różnej klasie wczesności. Biuletyn Instytutu Hodowli i Aklimatyzacji Roślin 231: 437-444.

Szulc P., Ambroży-Deręgowska K., Mejza I., Zawadzka A., Zielewicz W., Byczkiewicz S. (2020): The reaction of two types of maize cultivars (Zea mays L.) to different sowing density. Journal of Research and Applications in Agricultural Engineering 65 (2): $12-17$.

Szulc P., Ambroży-Deręgowska K., Waligóra H., Mejza I., Grześ S., Zielewicz W., Wróbel B. (2021): Dry matter yield of maize (Zea mays L.) as an indicator of mineral fertilizer efficiency. Plants 10, 535.

Szulc, P., Mejza, I., Ambroży-Deręgowska, K., Nowosad, K., Bocianowski, J. (2016): The comparison of three models applied to the analysis of three-factor trial on hybrid maize (Zea mays L.) cultivars. Biometrical Letters 53(1): 47-57.

Vafias B., Goulas C., Lolas G., Ipsilandis C.G. (2007): A triple stress effect on monogenotypic and multigenotypic maize populations. Asian Journal Plant Sciences 6: 29-35

Xu F., Wang B., He Ch., Liu D.L., Feng P., Yao N., Zhang R., Xu S., Xue J., Feng H., Yu Q., He J. (2021): Optimizing sowing date and planting density can mitigate the impacts of future climate on maize yield: A case study in the Guanzhong Plain of China. Agronomy 11: 1452.

Yu X., Zhang Q., Gao J., Wang Z., Borjigin Q., Hu S., Zhang B., Ma D. (2019): Planting density tolerance of high-yielding maize and the mechanisms underlying yield improvement with subsoiling and increased planting density. Agronomy 9, 370.

Zielewicz W., Wróbel B., Szulc P., Bujak H., Stachowiak B. (2021): By-plant prediction of dry matter yields at various growth stages of maize plants (Zea mays L.) using leaf greenness indicator in climatic conditions of Poland. Applied Sciences. 11. 9513. 